\title{
Effects of treated agro-industrial effluents on physical and chemical characteristics of the receiving stream Wawa in south-eastern Côte d'Ivoire
}

\author{
Martin Kouamé KOUAME ${ }^{1-2^{*}}$, Théophile GNAGNE ${ }^{2-3}$, Félix Koffi KONAN ${ }^{1-2}$, \\ Yves Kotchi BONY ${ }^{1}$ and Germain GOURENE ${ }^{1}$ \\ ${ }^{I}$ Université d'Abobo-Adjamé, Unité de Formation et de Recherche (UFR) en Sciences et Gestion de \\ l'Environnement (SGE), Laboratoire d'Environnement et de Biologie Aquatique (LEBA), \\ 02 BP 801 Abidjan 02, Côte d'Ivoire. \\ ${ }^{2}$ Centre Régional pour l'Eau Potable et l'Assainissement à faible coût / Représentation Nationale de Côte \\ d'Ivoire (CREPA-CI), Abidjan. 18 BP 80 Abidjan 18, Côte d'Ivoire. \\ ${ }^{3}$ Université d'Abobo-Adjamé, Unité de Formation et de Recherche (UFR) en Sciences et Gestion de \\ l'Environnement (SGE), Laboratoire Géoscience et Environnement (LGE), \\ 02 BP 801 Abidjan 02, Côte d'Ivoire. \\ *Corresponding author,Email: martin_kouame@yahoo.fr; Tel: (0225) 07648924 /(0225) 21758989
}

\begin{abstract}
In this research we examined the impact of effluents from an agro-industrial plant on River Wawa. Water quality was assessed by monitoring monthly during a year. Eleven parameters were retained: temperature, conductivity, dissolved oxygen, turbidity, $\mathrm{pH}$, chemical oxygen demand, nitrates, nitrites, ammonia, orthophosphates and organic pollution index. Except temperature and ammonia which didn't differ among sites, chemical oxygen demand and organic pollution index were significantly $(p<0.00001)$ higher at reference sites upstream the discharge point of effluents than sites located downstream. On the contrary, values of the other variables were significantly $(\mathrm{p}<0.05)$ higher at sites receiving the effluents. These results certainly support the hypothesis that the rejected effluents have a negative influence on the water quality downstream the discharge point. However, results suggest a decrease of the parameters content at the second site more distant from the discharge point, maybe due to the self-purifier capacity of the receiving stream. Ecological impacts not being all immediate, this wastewater could have a negative impact on the species living in the receiving stream in long term, either by bio-accumulation or by bio-magnification. It would be interesting to undertake complementary studies of bio-accumulation or bio-magnification on fauna.
\end{abstract}

(C) 2012 International Formulae Group. All rights reserved.

Keywords: Water pollution, industrial wastewater, wastewater discharge, water quality, pollution prevention.

\section{INTRODUCTION}

The rising of human activities leads to many physical and chemical aggressions of our environment due to installations and pollution. Water, a component of this environment, which is an important factor of the key sectors of development (Guerquin et al., 2003), represents a vital resource for human beings. The query of water is indisputably the environmental problems which have most mobilized the attention of the international community during the two 
last decades. In spite of its vital role, it also became, with the urban concentration, the receiver and the vector of waste. Indeed, according to Guerquin et al. (2003), approximately half of the wetlands are destroyed. Industries, cities and agriculture reject considerable quantities of effluents and various wastes more or less treated in the nature and contaminate sometimes this vital resource.

In Africa, urban wastewater treatment is not always a concern. Thus, rivers, crossing an urban centre or got through close to, constitute drains of pollution of any kind (liquid and solid). Indeed, these aquatic systems receive industrial wastewater and other urban effluents (Shrestha and Kazama, 2007). According to Dyer et al. (2003) and Chang (2005), anthropogenic pollution of rivers comes mainly from untreated wastewater or insufficiently treated effluents of treatment stations. The pollution of rivers, lakes and lagoons crossing some great cities of Africa perfectly illustrates this fact (e.g., the works of Mvungi et al. (2003) in Harare and Ameyapoh et al. (2005) in Lomé). Besides, the issue of agricultural pollution has been singled out as the most contributor of river water pollution (Schneider et al., 2000; Wetzel, 2001; Novotny et al., 2005).

However, in spite of the construction of purification station (STEP) by certain industrials, the problem of environment pollution by wastewater remains because of the dysfunction or the stop of these installations. Most industries use large volume of water but without efficient wastewater treatment plants; and so, routinely discharge their wastes directly into streams and rivers. The enrichment of water by nutriments from effluents discharge in aquatic environment involves a series of symptomatic changes such as the degradation of their physicochemical quality and other modifications considered as undesirable and harmful on the various uses of water (Fakayode, 2005). Thus, it results from it a degradation of the aquatic ecosystems which appears by the destruction of the habitat, the loss of biological diversity and the water quality. Wastewater could then be accountable of an irreversible ecological disequilibrium and eutrophication of the receiving environment (El Guamri et al., 2008). To face this situation, wastewater must undergo purification before being poured in the receiving environment.

In Côte d'Ivoire, the first cause of water quality deterioration of the rivers is their use for liquid wastes evacuation of cities and industries. Indeed, those cities and industries produce various effluents and wastes which are rejected in the sea, rivers or on the grounds, with or without prior treatment. Nevertheless, few societies such as SAPH, an agro-industrial firm, have built an effluent treatment system. Thus, effluents from this firm are treated before their rejection in the receiving stream, River Wawa in order to minimize their harmful effects. However, there is no investigation conducted on the harmful effects of such effluents on the stream's quality. Periodic monitoring of chemical and physical water quality indicators is therefore essential for assessing and/or protecting the integrity of the ecosystem. It has the advantages of identifying changes in water quality, early discovery of emerging water quality problems, the evaluation of pollution control measures, the effectiveness of compliance and how to respond in an emergency response (Adedokun et al., 2008).

The aim of this study is to evaluate the impact of the effluents rejection, an anthropic action, on the water quality of the receiving stream. Specifically, we tested to (i) evaluate the physicochemical characteristics of the effluents by determining some major and global parameters of wastewater pollution, (ii) determine the typology of the different sampling locations in the receiving stream by assessing their abiotic characteristics and (iii) determine the extent of intra and interseasonal variations for physicochemical variables in the different sites. 


\section{MATERIALS AND METHODS}

\section{Description of the study area}

The study area, Bongo-SAPH in River Amia basin (Figure 1), is located in the southeast of Côte d'Ivoire $\left(5^{\circ} 29^{\prime} \mathrm{N}\right.$ and $3^{\circ} 31^{\prime}$ $\mathrm{W})$. The region has an average altitude of 90 $\mathrm{m}$; its climate is subequatorial with an average annual temperature ranged between $25{ }^{\circ} \mathrm{C}$ to $33{ }^{\circ} \mathrm{C}$. The rainfall varied between 1400 to 2 $500 \mathrm{~mm} /$ year and an annual rate of humidity about 80 to $90 \%$ (Halle and Bruzon, 2006). This climate is characterised by two rainfall seasons (from mid-March to mid-July for the major and from October to November for the minor season) and two dry seasons (from midJuly to September for the minor and December to mid-March for the major season). According to Durand and Guiral (1994), floods appear between June and July for the most important, and between October and November for the less intense.

The research was carried out at six sampling stations, chosen following their position with reference to the discharge point of the industrial effluents in the stream (Figure 2). Four stations are located in the receiving stream: two upstream (RS1, RS2) as reference stations and two others downstream (SS1, SS2) of the discharge point as stressed stations. The two remaining stations (E1, E2) are located in the evacuation channel of the treated effluents in order to characterize the effluents discharged.

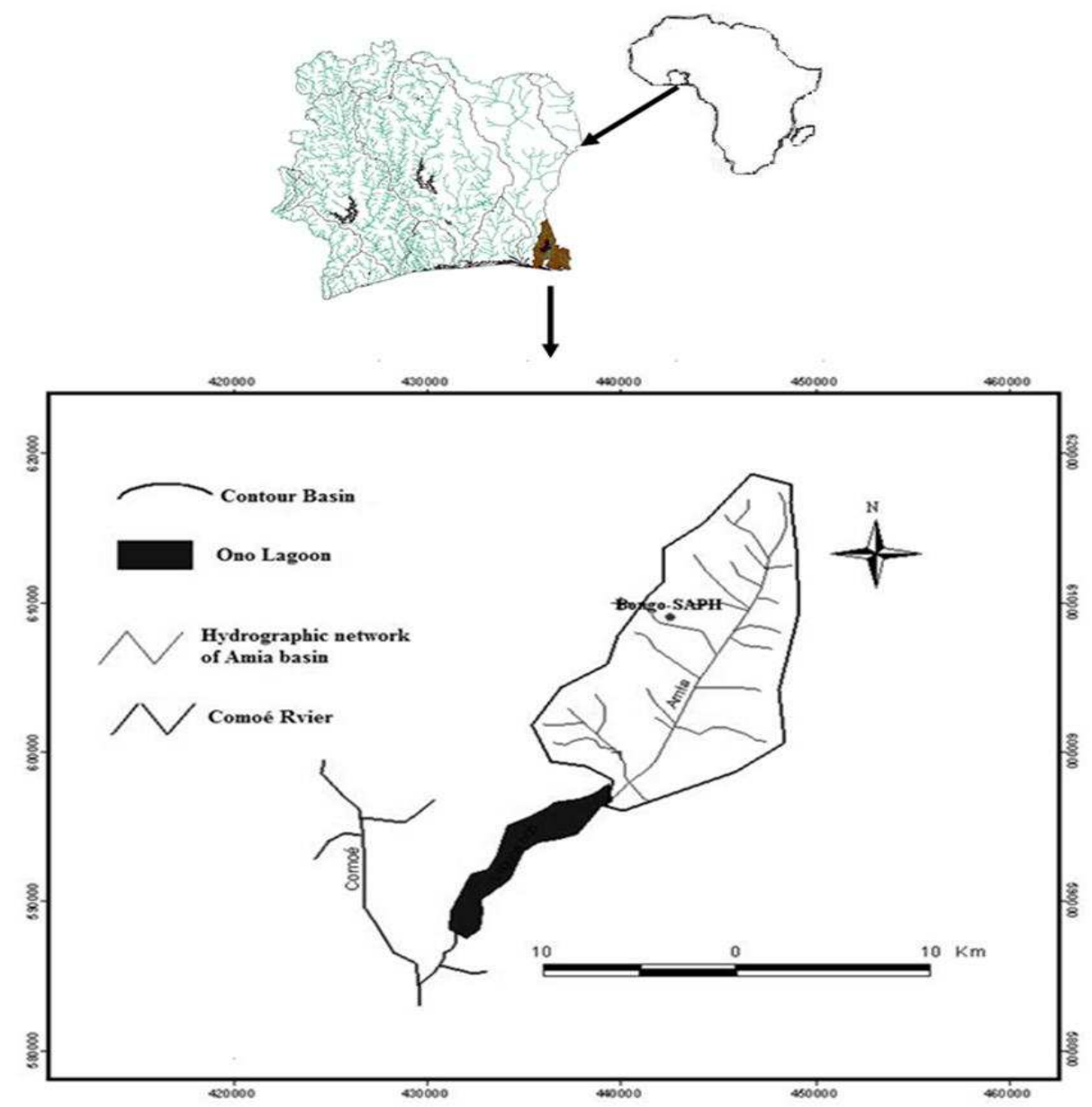

Figure 1: Catchment area of the studied stream at Bongo-SAPH (Alépé, Côte d'Ivoire). 


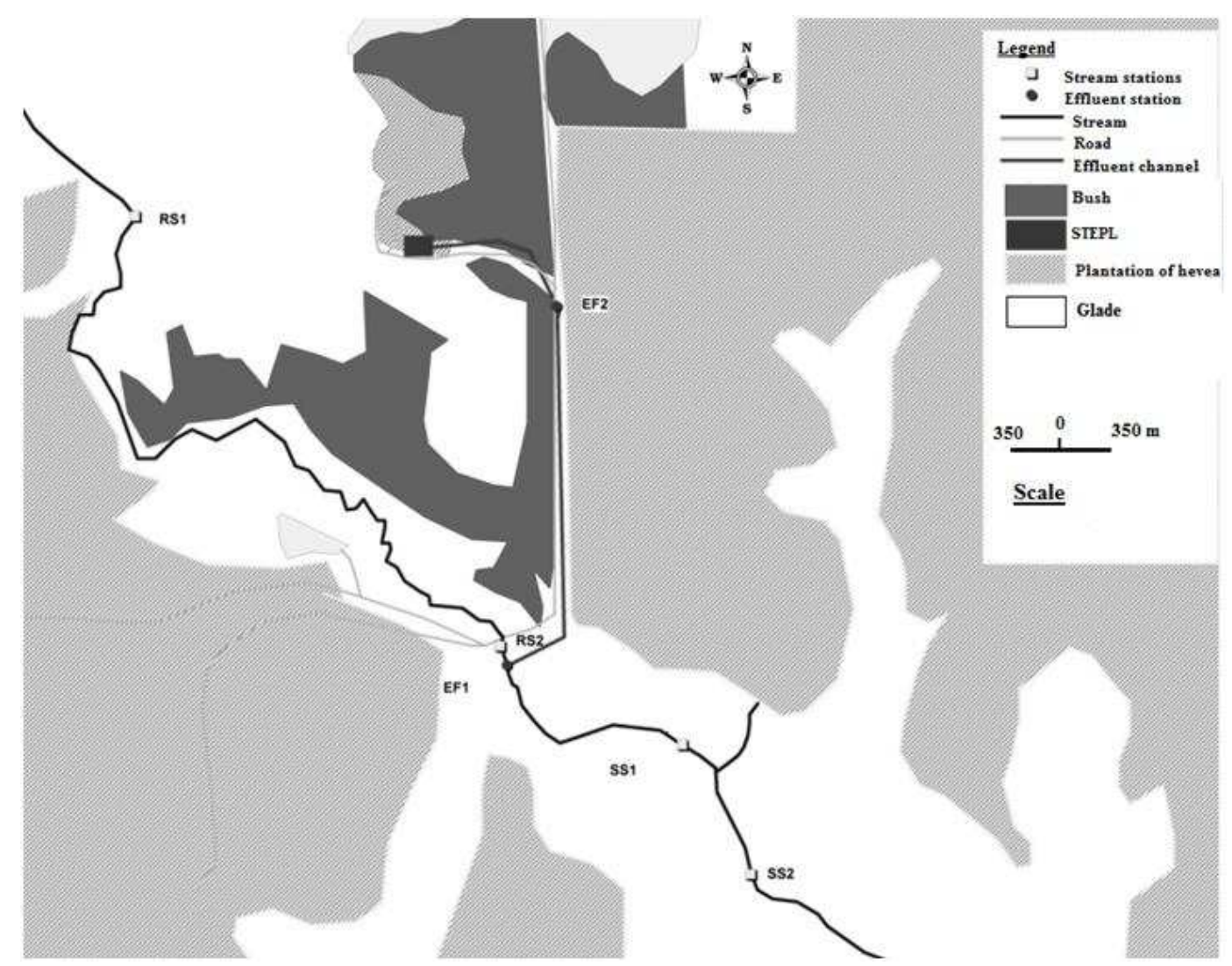

Figure 2: Schema showing the sampling locations on the receiving stream of effluents and on the channel discharge of effluents. EF1 = Site 1 on the effluents channel, EF2 = Site 2 on the effluents channel; RS1 = Reference site $1, \mathrm{RS} 2=$ Reference site $2 ; \mathrm{SS} 1=$ Stressed site $1, \mathrm{SS} 2=$ Stressed site 2.

\section{Field sampling}

Surveys were carried out monthly from October 2009 to September 2010 at each sampling stations. Collection of samples was done as much as possible before midday to minimise hourly variability of the day.

The maximum width of the channel and that of the river at each station were measured using a tape measure. Average depth was also measured along the longest axis at each station, with a stick marked at $1 \mathrm{~cm}$ intervals. Approximate flow velocity of the river and the effluents were estimated using the float method. Thus, current velocity $\left(\mathrm{m} \cdot \mathrm{s}^{-1}\right)$ was taken by timing a floating object over 5 meters stretch of the river five times with a chronometer at each station. Transparency (or
Secchi depth) was estimated with a $20 \mathrm{~cm}$ diameter black-white Secchi disc.

Dissolved oxygen (DO), expressed in $\mathrm{mg} / \mathrm{L}$ and $\%$ of saturation, and water temperature were measured in situ with a WTW Oxi 3205 oxygen-meter. Electric conductivity and $\mathrm{pH}$ were also measured with a WTW conductivity-meter and a WTW pHmeter respectively. At each of seven sampling stations, water samples were collected, preserved in $500 \mathrm{ml}$ polyethylene bottles and stored in ice for laboratory measurements of nitrite, nitrates, ammonia, phosphates, chemical oxygen demand (COD) and turbidity. Analysis of those chemical variables was done by means of a HACH DR/2010 spectrophotometer. To highlight the degree of organic pollution of water at the different 
sampling locations, we used the organic pollution index (OPI). This index determination is based on the contents of nitrites, ammonium and orthophosphates and on the values of the $\mathrm{DBO}_{5}$ (Leclercq and Maquet, 1987). Five quality classes are proposed for the values of this index included between 1 and 5: OPI > $4.6=$ null pollution, $4.6>$ OPI $>4=$ low pollution, $4>$ OPI $>3=$ moderate pollution, $3>$ OPI $>2=$ strong pollution and OPI $<2=$ very strong pollution.

\section{Statistical analyses}

Firstly, the nature of data was assessed to determine whether parametric or nonparametric methods were suitable. The Shapiro-Wilk (W) test was significant (p < 0.05 ) for all the variables, accepting the assumption of normality. Also, homogeneity of variances was tested and proved. Therefore data were analyzed by parametric tests, especially the ANOVA test for inter-stations differences in values of environmental variables considered.

\section{Description of patterns and relations between variables}

Prior to multivariate analysis, all physicochemical variables except $\mathrm{pH}$ (already a logarithm) were log-transformed. Therefore, Principal Components Analysis (PCA) was done in order to get an overall assessment of the possible relations among environmental variables in the considered stations and at each season.

The different analyses concerning PCA techniques were carried out using the software PAST 2.05 (Hammer et al., 2001). ANOVA and Shapiro-Wilk (W) tests were performed with the software Statistica 7.1 (Statsoft, 2005).

\section{RESULTS}

\section{Characteristics of the effluents}

Analysis of results showed that physicochemical variables of the effluents were not significantly different between the stations E1 and E2 located in the evacuation channel (ANOVA test, $\mathrm{p}>0.05$ ). Average values of those physicochemical characteristics of the treated effluents are shown in Table 1.

The temperature of the effluents ranged between $26.4{ }^{\circ} \mathrm{C}$ recorded in July and $29.6{ }^{\circ} \mathrm{C}$ in February, with an average value of 27.52 ${ }^{\circ} \mathrm{C}$. Generally, samples of effluents analyzed have a relatively neutral $\mathrm{pH}$ (7.35 as average value). Extremes values are 6.5 registered in June and 8.4 in December. Values of electric conductivity recorded varied between 475 $\mu \mathrm{S} / \mathrm{cm}$ in July and $1290 \mu \mathrm{s} / \mathrm{cm}$ in October, with an average value of $755.17 \mu \mathrm{S} / \mathrm{cm}$. The average concentration of dissolved oxygen was $3.25 \mathrm{mg} / \mathrm{L}$. Extreme values are $0.2 \mathrm{mg} / \mathrm{l}$ and $5.2 \mathrm{mg} / \mathrm{L}$, registered in October and June respectively.

Nitrates values recorded, like the other nitrogenous forms, present considerable variations during the study period. Concentrations vary between $0.13 \mathrm{mg} / \mathrm{L}$ recorded in February and $21.01 \mathrm{mg} / \mathrm{L}$ in October, with an average concentration of $5.62 \mathrm{mg} / \mathrm{L}$. On the other hand, them of Nitrites recorded in the discharges analyzed are included between $0.02 \mathrm{mg} / \mathrm{L}$ and $12.52 \mathrm{mg} / \mathrm{L}$, with an average value about $1.58 \mathrm{mg} / \mathrm{L}$. The lowest value was recorded in April while the highest was registered in September. Concerning ammonia, its contents oscillate between $0.25 \mathrm{mg} / \mathrm{L}$ (May) and $118.92 \mathrm{mg} / \mathrm{L}$ (October), with an average value about 39.88 $\mathrm{mg} / \mathrm{L}$. Values of orthophosphates registered varied between $0.31 \mathrm{mg} / \mathrm{L}$ (April) and 68.5 $\mathrm{mg} / \mathrm{L}$ (August) during the period of sampling, with an average value of $29.08 \mathrm{mg} / \mathrm{L}$.

Values of organic pollution expressed as OPI present negligible variations between the different campaigns of sampling. Values recorded are comprised between 1 and 2 with an average value of 1.5 . Those values indicate a very strong organic pollution of the effluents discharged in the streams water. Concentrations values of oxidable matters, 
expressed in this study by COD values, are very significant. Those values of COD oscillated between $16.21 \mathrm{mg} / \mathrm{L}$ and 766.05 $\mathrm{mg} / \mathrm{L}$, with an average of $172.68 \mathrm{mg} / \mathrm{L}$. The lowest concentration was recorded in February while the highest was observed in September.

Evolution of the physical and chemical parameters of the receiving stream water along the measurement stations

Results of analyses for the physicochemical parameters of stream water are presented in Figure 3.

Variations of temperature, conductivity, $\mathrm{pH}$, dissolved oxygen and turbidity

Average values of water temperature at the different stations along the receiving stream vary between $25.43{ }^{\circ} \mathrm{C}$ at the two reference sites (RS1 and RS2) and $25.80{ }^{\circ} \mathrm{C}$ at the two sites downstream the discharged point (SS1 and SS2). However, significant variations among those stations were not observed according to the test of ANOVA ( $p$ $>0.05)$.

The average values obtained for conductivity per sites are included between $26.38 \mu \mathrm{S} / \mathrm{cm}$ and $64.63 \mu \mathrm{S} / \mathrm{cm}$. The lowest value was obtained upstream the discharge point of the effluents (RS1), while the greatest was observed downstream (SS1). Significant differences (ANOVA test, $\mathrm{p}<0.0001$ ) were noticed between the two reference sites (RS1, $\mathrm{RS} 2$ ) and the two others (SS1, SS2). However, a decrease of the contents of conductivity was registered from the first site SS1 $(64.63 \mu \mathrm{S} / \mathrm{cm})$ downstream the discharge point of the effluents to the second one SS2 (58.08 $\mu \mathrm{S} / \mathrm{cm})$.

Values of $\mathrm{pH}$ showed that the water of the receiving stream is generally acid (5.31 to 5.95). According to the ANOVA test ( $\mathrm{p}=$ 0.000007), significant difference has been noticed between the reference stations (RS1, RS2) and the stressed stations (SS1, SS2) which showed the highest values (about 6).
The results obtained indicated that the stations located upstream the discharge point of the effluents (RS1, RS2) are more oxygenated, especially RS1 (5.3 mg/l) which is more distant from this point, than those downstream (SS1: 3.14 and SS2: $2.68 \mathrm{mg} / \mathrm{l}$ ). A significant difference has been registered between RS1 and all the other sampling locations and between RS2 and SS2 (ANOVA test, $\mathrm{p}<0.00001)$.

As for the turbidity, average values observed varied significantly (ANOVA test, $p$ $=0.0037$ ) between the sampling location SS1 (16.07 NTU) and the reference stations (RS1: 7.05; RS2: 10.03 NTU). Thus, this stressed station SS1 indicated the strongest turbidity while the lowest was observed at the reference station RS1.

Evolution of the nutrients: nitrogenous forms and phosphates

Concerning the whole reference stations, average phosphates concentrations are low: $0.15 \mathrm{mg} / \mathrm{L}$ for RS1 and $0.19 \mathrm{mg} / \mathrm{L}$ for RS2. Average values obtained at the stressed stations are 3.23 and $1.63 \mathrm{mg} / \mathrm{L}$ for SS1 and SS2 respectively. Great significant differences have been observed between those stressed stations and the reference sites according to the ANOVA test $(\mathrm{p}=0.000001)$.

Average values of nitrates obtained ranged between 2.00 and $9.71 \mathrm{mg} / \mathrm{L}$ ). Significant difference was only observed between the reference site RS2 where the lowest value is registered $(2.00 \mathrm{mg} / \mathrm{L})$ and the stressed site SS2 which showed the higher value $(9.71 \mathrm{mg} / \mathrm{L})$.

Ammonia average concentrations varied from $0.78 \mathrm{mg} / \mathrm{L}$ to $1.54 \mathrm{mg} / \mathrm{L}$ for the whole of the stations. Significant variations were not observed among the different stations (ANOVA test, $\mathrm{p}=0.49$ ). However, the highest value observed at the stressed site 1 (SS1) decreased at the second stressed site (SS2) at which the lowest concentration has been registered. 
Mean values of nitrites oscillated between $0.003 \mathrm{mg} / \mathrm{L}$ and $0.61 \mathrm{mg} / \mathrm{L}$. The lowest values were observed at the reference stations RS1 and RS2, respectively 0.003 and $0.01 \mathrm{mg} / \mathrm{L}$, while the highest value is registered at the stressed site SS1. According to the ANOVA test ( $\mathrm{p}=0.011$ ), significant differences were revealed between the reference sites (RS1, RS2) and the stressed site SS1.

\section{Organic pollution}

Mean values of chemical oxygen demand (COD) oscillated between 15.36 $\mathrm{mg} / \mathrm{L}$ (RS1) and $40.52 \mathrm{mg} / \mathrm{L}$ (SS2) in the different sampling locations. Significant variations (ANOVA test, $\mathrm{p}=0.0287$ ) were observed among the sampling locations downstream the discharge point of the effluents (SS1, SS2) and the reference stations (RS1, RS2). Highest values were registered at the stressed sites SS1 (39.49 mg/L) and SS2 (40.52 mg/L).

Organic Pollution Index (OPI) Values ranged between 1.97 (SS1) and 4.14 (RS1). Pollution level, according to OPI values, indicated low organic pollution in RS1 and moderate pollution in RS2 (3.94). The station SS2 showed a strong organic pollution state (2.67), while SS1, the sampling location nearer to the discharge point of the effluents downstream, indicated a very strong organic pollution (OPI = 1.97). Besides, results of the ANOVA test $(\mathrm{p}<0.00001)$ revealed a significant difference among the two groups of sampling locations, reference sites (RS1, RS2) and stressed sites (SS1, SS2).

Ordination of sampling locations on the receiving stream in relation with environmental variables

The PCA axis 1 and 2 explained respectively $30.2 \%$ and $14.5 \%$ of variability in the physicochemical characteristics (Figure 4). These axes explained together $44.7 \%$ of total variation. Axis 1 divided the stations in two groups: one group composed of the reference sites in the negative part and another group constituted of the stressed sites in the positive part. This axis mainly represented a significant and positive gradient of conductivity, $\mathrm{pH}$ and phosphates (Figure 5). The same axis was significantly and negatively associated with gradients in OPI (organic pollution index) values.

The results of PCA revealed that the reference sites were associated with important amount of dissolved oxygen and greater values of OPI, while stressed sites were associated with higher values of $\mathrm{pH}$, conductivity, phosphates and turbidity gradients. However, it is observed that values of $\mathrm{pH}$, conductivity, phosphates and turbidity decreased at the site SS2 which is more discarded from the discharge point of effluents. Thus, it seemed that there was a natural restoration of the water quality by the receiving stream.

\section{Characteristics of auto-purification on the receiving stream}

Evolution of physical and chemical parameters considered is illustrated on Figure 6. Auto-purification kinetics of the stream has been evaluated on $1 \mathrm{~km}$. Downstream the discharge point of the effluents rejections were clearly perceptible in the stream, loads upstream being different from those of rejection. But, auto-purification kinetic in stream was very strong (up to $98 \%$ per $\mathrm{km}$ for NH4, 94\% for PO4, 93\% for turbidity, 92\% for conductivity and $78 \%$ per $\mathrm{km}$ for COD). Values of the whole parameters decreased on $500 \mathrm{~m}$ from the discharge point of the effluents to the first station downstream and from this station to the second one also on 500 $\mathrm{m}$. Auto-purification kinetics were more than $90 \%$ for conductivity, turbidity, orthophosphates and ammonia between the discharge point and the first station downstream. 

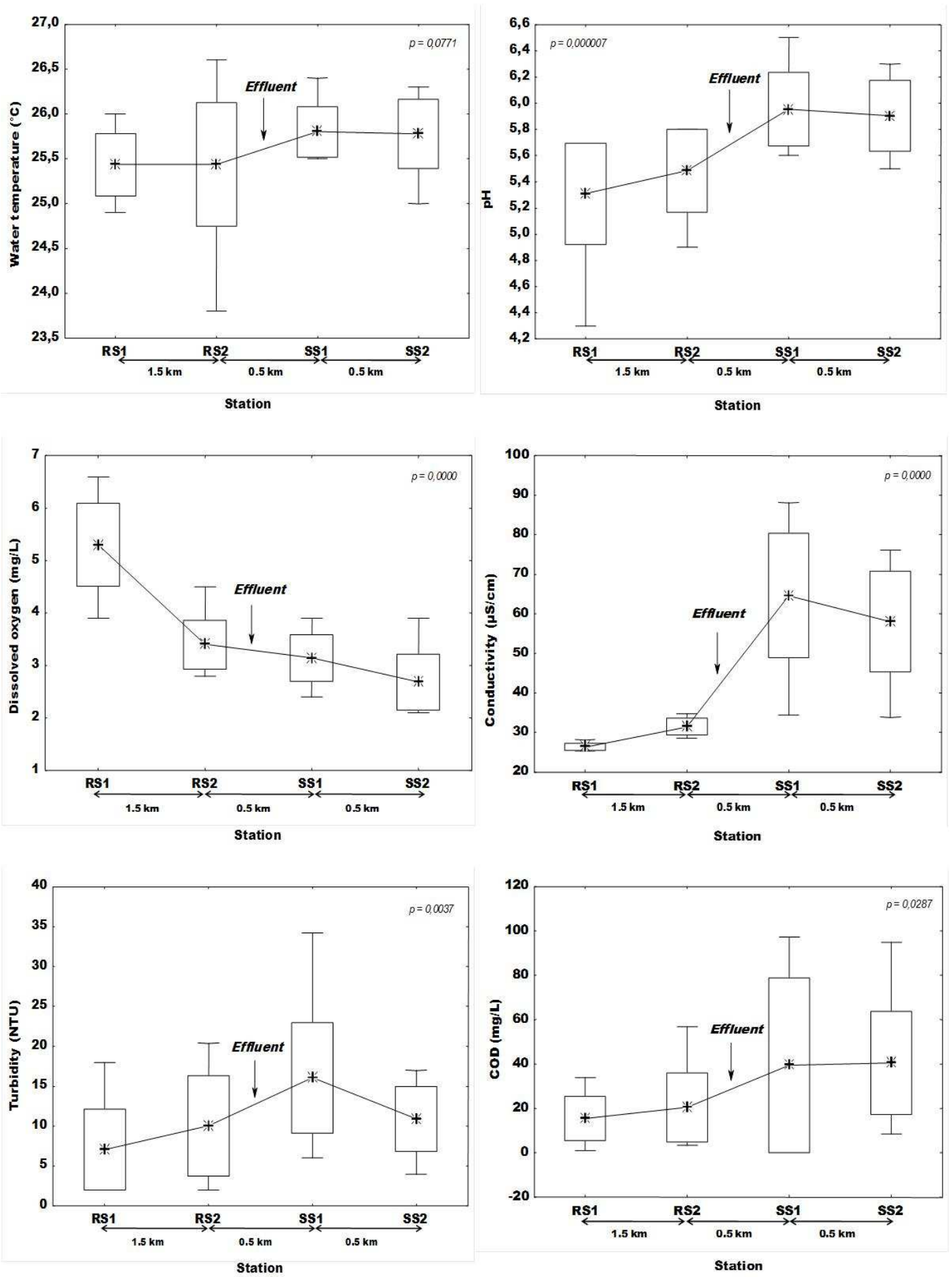

Figure 3 a: Evolution of the physicochemical parameters in ordination of sampling locations along the measurement stations located on the receiving stream in Bongo-SAPH (Alépé, Côte d'Ivoire). RS1 and RS2 represent the reference sites; SS1 and SS2 are the stressed sites downstream the discharge point. 

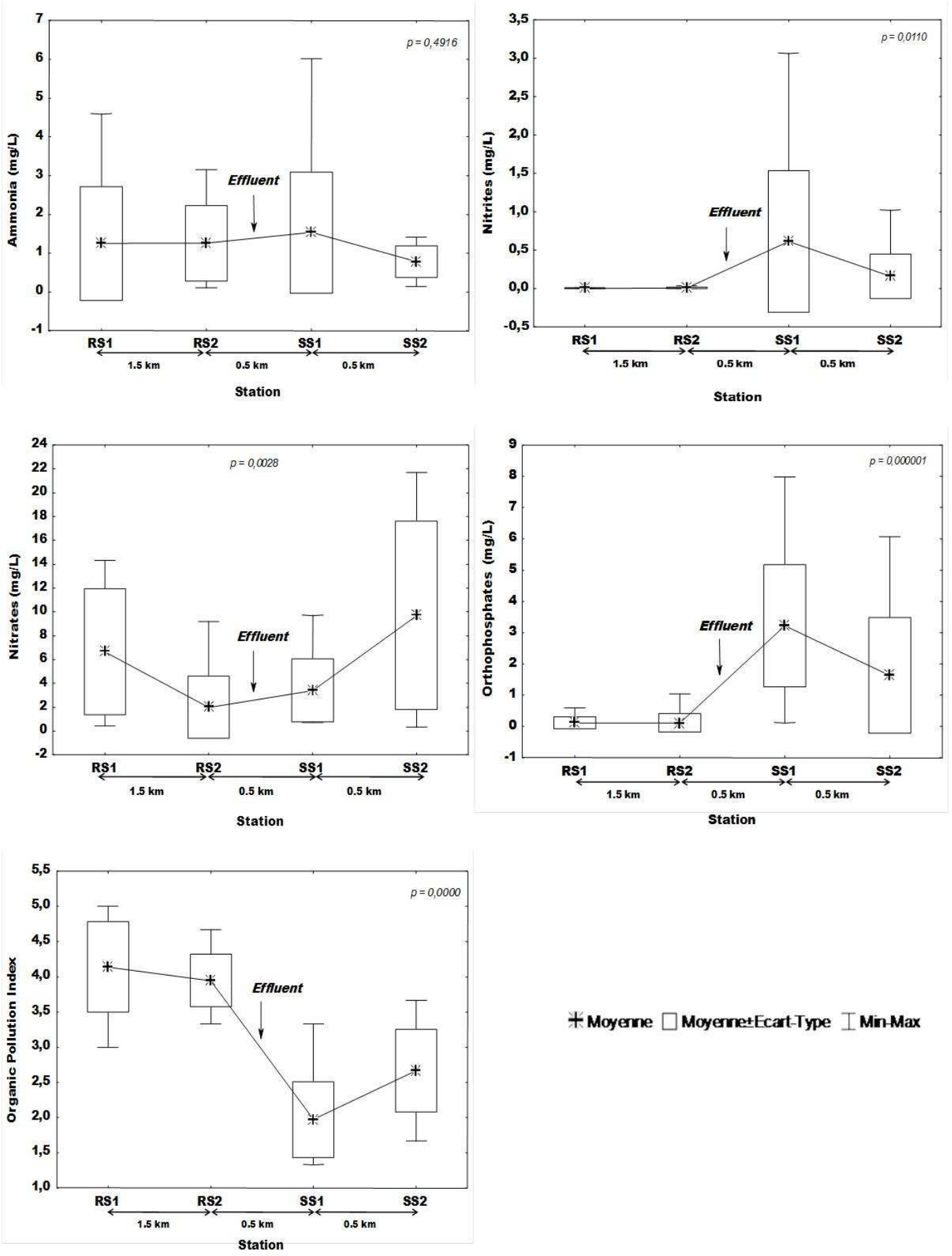

+ Moyerne $\square$ MoyennetEcart-Type I MinMax

Figure 3b (concluded): Evolution of the physicochemical parameters in ordination of sampling locations along the measurement stations located on the receiving stream in Bongo-SAPH (Alépé, Côte d'Ivoire). RS1 and RS2 represent the reference sites; SS1 and SS2 are the stressed sites downstream the discharge point. 


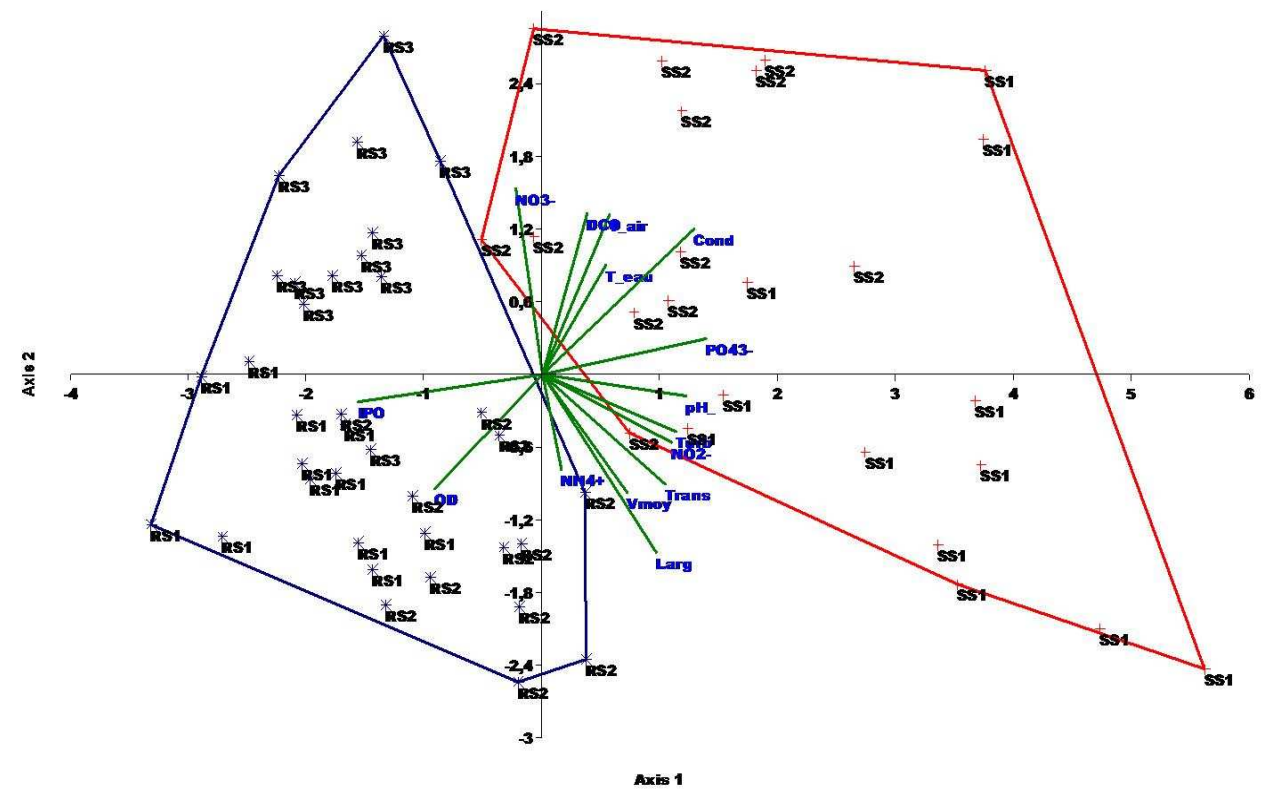

Figure 4: A Principal Components Analysis (PCA) ordination biplot of the relations between environmental variables recorded at the reference sampling locations (blue convex hulls) and the stressed sampling locations (red convex hulls) in the receiving stream of the agro-industrial effluents.

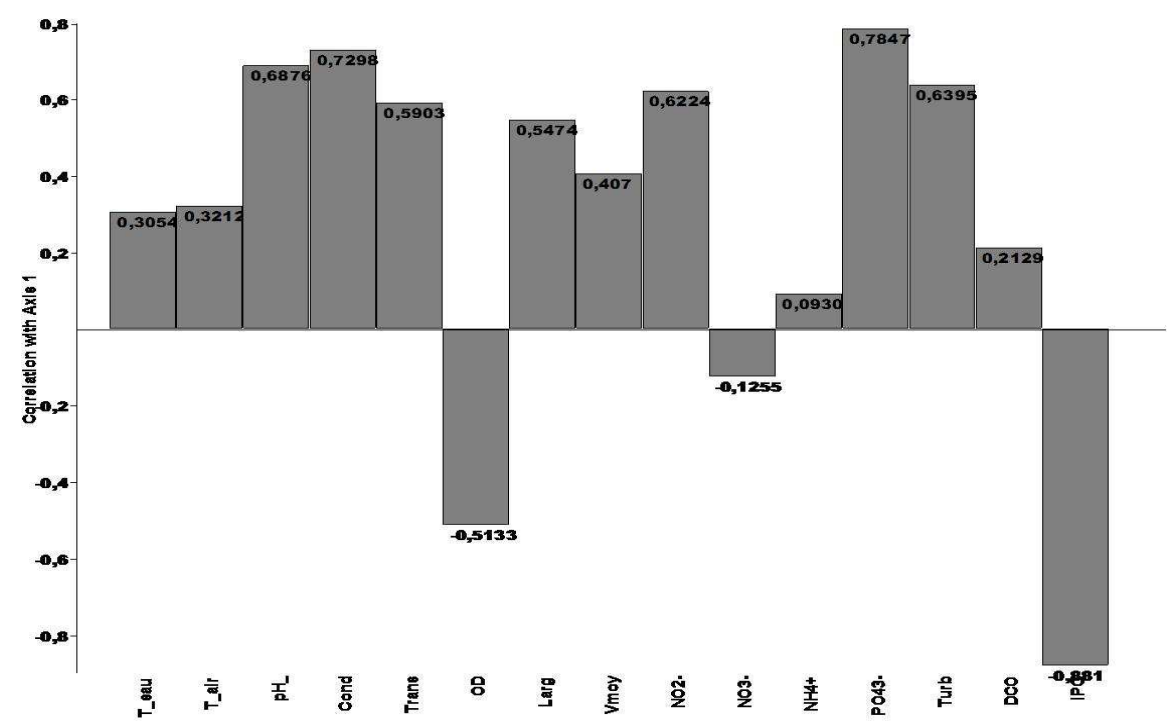

Figure 5: Correlation coefficients of environmental variables in relation with the PCA axis 1. 

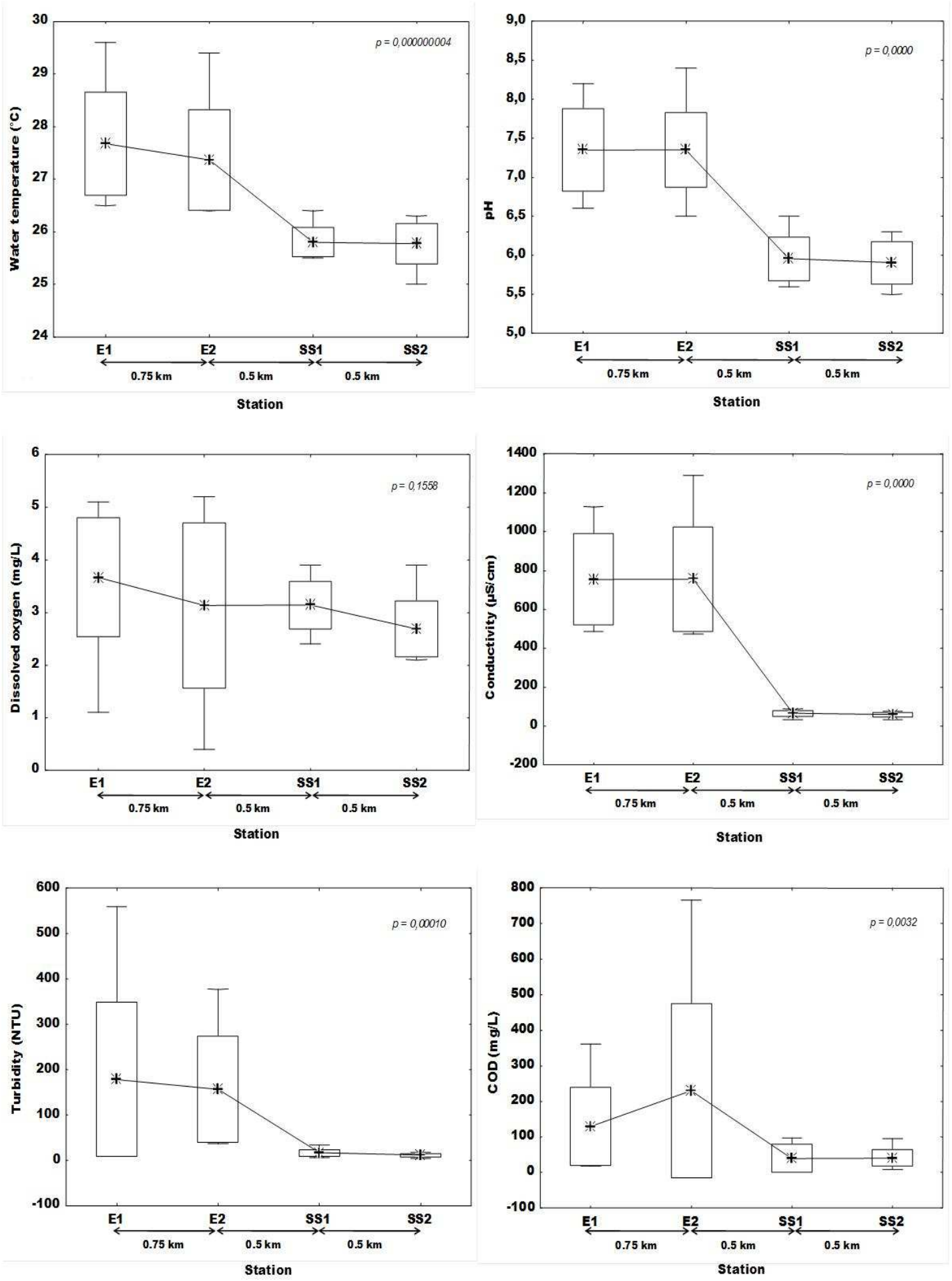

Figure 6a: Evolution of the physicochemical parameters in ordination of sampling locations along the measurement stations located on the effluents channel (E1, E2) and those downstream the discharge point (SS1, SS2) in the receiving stream in Bongo-SAPH (Alépé, Côte d'Ivoire). 

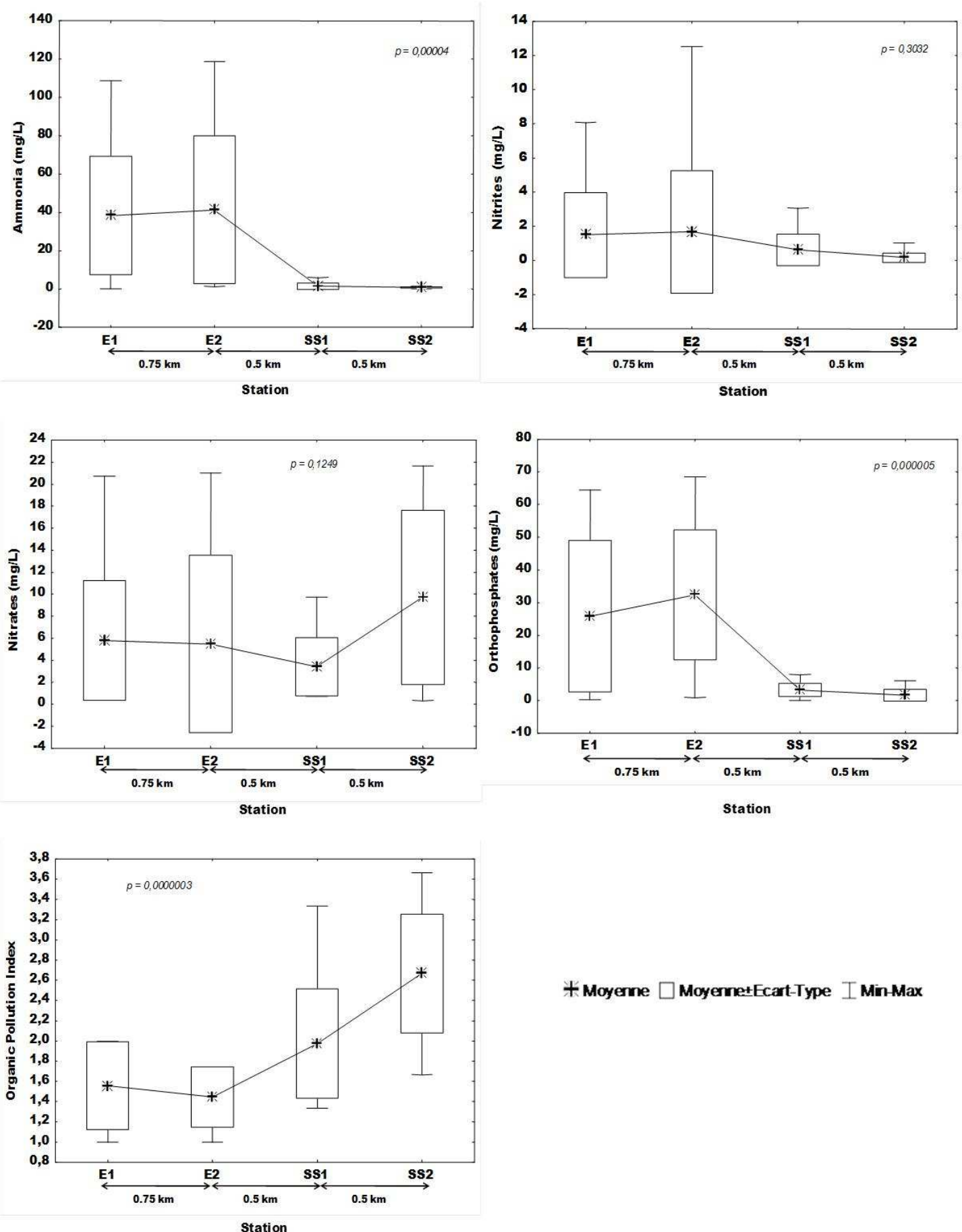

* Moyeme $\square$ MoyennetEcart-Type I MinMax

Figure 6b (concluded): Evolution of the physicochemical parameters in ordination of sampling locations along the measurement stations located on the effluents channel (E1, E2) and those downstream the discharge point (SS1, SS2) in the receiving stream in Bongo-SAPH (Alépé, Côte d'Ivoire). 
Table 1: Average values of the physicochemical characteristics of the pre-treated effluents of the agro-industrial plant discharged in the stream.

\begin{tabular}{lccccc}
\hline Abiotic parameters & Average & SD & Minimum & Maximum & N-active \\
\hline Temperature $\left({ }^{\circ} \mathrm{C}\right)$ & 27.52 & 0.96 & 26.40 & 29.60 & 24 \\
$\mathrm{pH}$ & 7.35 & 0.49 & 6.50 & 8.40 & 24 \\
Conductivity $(\mu \mathrm{S} / \mathrm{cm})$ & 755.17 & 246.84 & 475.00 & 1290.00 & 24 \\
Dissolved oxygen $(\mathrm{mg} / \mathrm{L})$ & 3.25 & 1.51 & 0.20 & 5.20 & 24 \\
Nitrites $(\mathrm{mg} / \mathrm{L})$ & 1.58 & 3.02 & 0.02 & 12.52 & 24 \\
Nitrates $(\mathrm{mg} / \mathrm{L})$ & 5.62 & 6.73 & 0.13 & 21.01 & 24 \\
Ammonia $(\mathrm{mg} / \mathrm{L})$ & 39.88 & 34.22 & 0.25 & 118.92 & 24 \\
Orthophosphates $(\mathrm{mg} / \mathrm{L})$ & 29.08 & 21.45 & 0.31 & 68.50 & 24 \\
Turbidity $(\mathrm{NTU})$ & 167.25 & 143.21 & 33.00 & 559.20 & 24 \\
DCO (mg/L) & 340.37 & 883.04 & 16.21 & 4403.24 & 24 \\
Organic Pollution Index & 1.50 & 0.37 & 1.00 & 2.00 & 24 \\
\hline SD = standard deviation, $\mathrm{N}-\mathrm{active}=$ number of samplings. & & &
\end{tabular}

\section{DISCUSSION}

The results show that values of conductivity ( 25.40 to $34.80 \mu \mathrm{S} / \mathrm{cm}$ ) at the reference sites, upstream the discharge point of the effluents, are lower than those of stressed sites downstream (33.90 to 88.10 $\mu \mathrm{S} / \mathrm{cm})$. These results showed that reference sites are less mineralized, while sites downstream the discharge point of the effluents are more mineralized. High level of conductivity (about $756 \mu \mathrm{S} / \mathrm{cm}$ ) registered in the effluents could explain the increase of conductivity observed from upstream towards downstream. Indeed, the effluents discharged in the stream carried solids particles which decompose into more or less fine particles and/or mineralize. Average value of effluents temperature $\left(27.52{ }^{\circ} \mathrm{C}\right)$ is in accordance with Senegalese and Ivorian rejection norm of effluents in the receiving area which are limit to $30{ }^{\circ} \mathrm{C}$ and $40{ }^{\circ} \mathrm{C}$ respectively. The results revealed that the sampling locations upstream the discharge point of the effluents are more oxygenated, than those downstream. Those results show therefore a degree of pollution more significant downstream the discharge point. However, a reduction in the dissolved oxygen value in the downstream zone of the discharge point when compared with the values obtained upstream is indicative of enormous amount of organic loads which required high level of oxygen for chemical oxidation and decomposition. Evaluation of dissolved oxygen is crucial to the survival of aquatic organisms and ultimately in establishing the degree of freshness of a river (Fakayode, 2005). In addition, the lower values of dissolved oxygen concentration observed at the stations downstream the discharge point would be related to the strongest turbidity observed at those stations. Indeed, strong turbidity in water column favours the reduction of luminosity and reduces the biological production due, in particular, to a drop of dissolved oxygen consecutive to a reduction of photosynthesis phenomena. This phenomenon has therefore been subject to the influence of the effluents coming from the station of wastewater treatment. Indeed, average value of those effluents turbidity was 167.25 NTU. Average values of $\mathrm{pH}$ (5.31 to 5.95) registered at the 
different stations in the stream are located within the tolerable limit (5 to 9) for the majority of vegetable and animal species and particularly fish. The survival of aquatic organisms is greatly influenced by the $\mathrm{pH}$ of water bodies in which they are found (Osibanjo et al., 2011). Beyond pH 9, there is mortality for many species. This is because most of their metabolic activities are $\mathrm{pH}$ dependent (Wang et al., 2002). Taking into consideration this report, values of $\mathrm{pH}$ obtained are acceptable. Indeed, those values are in accordance with Ivorian standard of effluents $\mathrm{pH}$ which is fixed between 5.5 and 8.5 or 5.5 and 9.5 en case of chemical treatment.

At the different stations located on the receiving stream, mean concentrations of phosphates varied from 0.15 to $0.19 \mathrm{mg} / \mathrm{L}$ for reference stations and 1.63 to $3.23 \mathrm{mg} / \mathrm{L}$ for stations downstream the discharged point of the effluents. Highest value of phosphates observed at the stressed stations would come from the effluents discharged in the stream. Indeed, those effluents had average concentration of phosphates which was 29.08 $\mathrm{mg} / \mathrm{L}$. Thus, discharges of industrial effluents with high phosphate content might be responsible for the increased levels observed downstream. High levels of phosphates and other nutrients encourage eutrophication which could further deplete the dissolved oxygen levels of the rivers (Fakayode, 2005; Minareci et al., 2009). Mean values of nitrates obtained in the receiving stream, lower than Ivorian standard for nitrogen concentration in effluents $(50 \mathrm{mg} / \mathrm{L})$, lie between 2.00 and 9.71 $\mathrm{mg} / \mathrm{L}$. Those low values may explain low values of nitrites registered which were very low $(0.003$ to $0.61 \mathrm{mg} / \mathrm{L})$. The receiving river can be regarded as a river of good quality on the basis of nitrates contents. Indeed, according to Beaux (1998), a river having a concentration of nitrates lower than $44 \mathrm{mg} / \mathrm{L}$ can be regarded as having a water of good quality. Ammonia average concentrations are relatively low $(0.78 \mathrm{mg} / \mathrm{L}$ to $1.54 \mathrm{mg} / \mathrm{L})$ for the whole of the stations located on the stream. Therefore, there is less risks for aquatic life.

Highest values of COD and lowest values of IPO were registered at the stations downstream the discharge point. These results showed that reference sites are slightly polluted or not, while stressed sites, downstream the discharge point of the effluents, are strongly polluted. This reveals the impact of the agro-industrial effluents on the river downstream the discharge point. The river had appreciable increases in COD values in this zone, confirming the impact of industrial discharges on the original quality of the rivers. Indeed, the results of physicochemical analysis of the effluents give COD concentrations ranging between 16.21 $\mathrm{mg} / \mathrm{L}$ and $766.05 \mathrm{mg} / \mathrm{L}$ with an average of $179.87 \mathrm{mg} / \mathrm{L}$. Thus, this average value of the treated wastewater, higher than the standard of rejection $(<150 \mathrm{mg} / \mathrm{L})$, revealed that the effluents rejected are very charged out of organic matter expressed in COD term. These concentrations, higher than the Senegalese rejection norms of effluents, may have a negative effect on aquatic organisms according to Lamizana-Diallo (2005). However, a dilution effect of those concentrations was observed in the receiving stream, considering values measured at the sampling locations downstream the discharge point. Purification kinetics in stream was very strong (up to $98 \%$ per $\mathrm{km}$ for $\mathrm{NH} 4,94 \%$ for PO4 and $78 \%$ per $\mathrm{km}$ for COD). Thus, the stream could find its state of reference very quickly, per example after approximately one kilometre and half.

All things considered, a decrease of contents of the measured parameters was observed at the station SS2 which is more distant from the discharge point of the effluents. This decrease of concentrations may be due to the selfpurifier capacity of the receiving stream. Thus, there was an effect of wastewater 
dilution attenuating the concentrations of the various parameters considered in this study. In addition, nutrients (nitrates, nitrites, ammonia and phosphates) may be diluted as they are washed downstream by current. However, the results show that there was pollution of the river's zone downstream the discharge point. Ecological impacts not being all immediate, this wastewater could have a negative impact on the species living in the receiving area in long term, either by bio-accumulation or by bio-magnification. It would be interesting to undertake complementary studies of bioaccumulation or bio-magnification on fauna.

\section{ACKNOWLEDGEMENTS}

This study was financially supported by the International Foundation for Science, Stockholm, Sweden, through a grant to $\mathrm{Mr}$ Kouamé K. Martin and benefited from collaboration with the "Centre Régional pour l'Eau Potable et l'Assainissement à faible coût; Représentation Nationale de Côte d'Ivoire (CREPA-CI)".

We thank Kpaï Natty N., Ahizi N. Michel, Konan K. Théodore and N'guessan Francis from "Laboratoire d'Environnement et de Biologie Aquatique (LEBA)" of AboboAdjamé University for their invaluable field assistance for data collection. Kouamé Y. Francis, Kossonou Roland and Gnagne Agness from "Laboratoire des Sciences de l'Environnement (LSE)" of Abobo-Adjamé University are thanked for providing useful assistance for the whole of laboratory analyses.

\section{REFERENCES}

Adedokun OA, Adeyemo OK, Adeleye E, Yusuf RK. 2008. Seasonal limnological variation and nutrient load of the river system in Ibadan metropolis, Nigeria. European Journal Sciences Research, 23(1): 98-108.

Ameyapoh Y, Hiheglo M, Bawa LM, De Souza C. 2005. Impacts des contaminations microbienne et chimique de la lagune de Lomé sur la qualité des poissons péchés dans ses eaux. Ecole Supérieure des Techniques Biologiques et Alimentaires (ESTBA), Université de Lomé, Togo, p 4.

Beaux JF. 1998. L'Environnement-Repères Pratiques. Nathan, ISBN 2-09-18243-3; 64-71.

Chang H. 2005. Spatial and temporal variations of water quality in the Han River and its tributaries, Seoul, Korea. Water, Air, and Soil Pollution, 161: 267284.

Durand JR, Guiral D. 1994. Hydroclimat et hydrochimie. In Environnement et Ressources Aquatiques de Côte d'Ivoire. Tome II, Les Milieux Lagunaires, Durand JR, Dufour P, Guiral D, Zabi SGF (eds). Édition ORSTOM: Paris; 59-90.

Dyer SD, Peng C, McAvoy DC, Fendinger NJ, Masscheleyn P, Castillo LV, Lim JMU. 2003. The influence of untreated wastewater to aquatic communities in the Balatuin River, The Philippines. Chemosphere, 52:43-53.

El Guamri Y, Belghyti D, El Kharrim Kh, Raweh S, Sylla I, Benyakhef M. 2008. Etude physico-chimique des eaux usées brutes de l'abattoir municipal de Kénitra (Maroc) en vu de la mise en œuvre d'un traitement convenable. Sud Sciences et Technologies, 16: 36-43.

Fakayode SO. 2005. Impact assessment of industrial effluent on water quality of the receiving Alaro River in Ibadan, Nigeria. AJEAMRAGEE, 10: 1-13.

Guerquin F, Tarek A, Mi H, Tetsuya I, Vedat O, Marlies S. 2003. World Water Actions: Making Water Flow for All. WWC (World Water Council), Water Action Unit, Earthscan Publications Ltd: London.

Halle B, Bruzon V. 2006. Profil environnemental de la Côte d'Ivoire. 
Rapport final de la Commission Européenne, p. 133.

Hammer O, Harper DAT, Ryan PD. 2001. Paleontological statistics software package for education and data analysis. Paleontologica Electronica 4(1): 9.

Lamizana-Diallo MB. 2005. Effet du régime de la crue naturelle fluviale sur les hygrophytes. Cas d'un bief du Massili, Burkina Faso. Mémoire de DEA. Université de Ouagadougou, Ouagadougou, p. 77.

Leclercq L, Maquet B. 1987. Deux nouveaux indices chimiques et diatomiques de qualité d'eau courante. Application au Samson et à ses affluents (Bassin de la Meuse belge). Comparaison avec d'autres indices chimiques, biocénotiques et diatomiques. Institut Royal des Sciences Naturelles de Belgique, Document de travail, p. 113.

Minareci O, Ozturk M, Egemen O, Minareci E. 2009. Detergent and phosphate pollution in Gediz River, Turkey. African Journal of Biotechnology, 8(15): 35683575.

Mvungi A, Hranova RK, Love DJ. 2003. Impact of home industries on water quality in a tributary of the Marimba River, Harare: implications for urban water management. Physics and Chemistry of the Earth, 28: 1131-1137.

Novotny V, Bartovosa A, O'Reilly N, Ehlinger T. 2005. Unlocking the relationship of biotic integrity of impaired waters to anthropogenic stresses. Water resources, 39: 184-198.

Osibanjo O, Daso AP, Gbadebo AM. 2011 The impact of industries on surface water quality of River Ona and River Alaro in Oluyole Industrial Estate, Ibadan, Nigeria. African Journal of Biotechnology, 10(4): 696-702.

Schneider S, Schranz C, Melzer A. 2000. Indicating the trophic state of running waters by submersed macrophytes and epilitic diatoms. Exemplary implementation of a new classification of taxa into trophic classes. Limnologica, 30: $1-8$.

Shrestha S, Kazama F. 2007. Assessment of surface water quality using multivariate statistical techniques: A case study of the Fuji river basin, Japan. Environmental Modelling and Software, 22: 464-475.

StatSoft, 2005. STATISTICA (Data Analysis Software System), Version 7.1. Tulsa OK, StatSoft.

Wang W, Wang A, Chen L, Liu Y, Sun R. 2002. Effects of $\mathrm{pH}$ on survival, phosphorus concentration, adenylate energy charge and $\mathrm{Na}+$ - $\mathrm{K}+$ ATPase activities of Penaeus chinensis Osbeck juveniles. Aquatic Toxicology, 60: 75-83.

Wetzel RG. 2001. Limnology: Lake and River Ecosystems. Academic: London. 